\title{
Study of Biochemical Parameters in Sera of Diabetes Mellitus DM (Type 1) Patients with Nephropathy and Myocardial Vascular Disease Complication
}

\author{
Perry H. Saifullah", Saad Mohammed Nida** and Israa Burhan Raoof ${ }^{* * *}$ \\ * Department of Chemistry, College of Science for Women, University of Baghdad. \\ ** Department of Biotechnology, Biotechnology Research Center, Al-Nahrian University. \\ **** Department of Clinical Lab Science, College of Pharmacy, Al-Mustansiriyah University.
}

\begin{abstract}
Type 1 diabetes mellitus is a disease caused by the progressive and selective destruction, by autoimmune mechanisms, of pancreatic beta cells. The aim of this study was to detecting antibodies against DNA in Type 1 Diabetes mellitus DM patients with nephropathy and myocardial vascular disease complication the Study was done of 80 samples of blood and serum of woman were obtained under fasting conditions and they divided as:20 samples of patients of DM, DM with CV, DM with Nephropathy and Subjects as control group in National Diabetes Center (NDC), with average age about (13-67) years to measure level of lipid, urea, glucose-6-phosphate dehydrogenase. The study showed elevated in level of lipid profile, urea in patients, auto immune antibody compared with control group
\end{abstract}

Keywords: diabetes mellitus disease, autoantibody, ELISA.

\section{Introduction}

Diabetes mellitus, a common metabolic disorder resulting from defects in insulin secretion or action or both, is characterized by hyperglycemia often accompanied by glycosuria, polydipsia, and polyuria [1] Type I (insulin-dependent) diabetes mellitus is caused by an autoimmune process that leads to inappropriate inflammation directed at the pancreatic islets [2] it fact that Type I diabetes results from an autoimmune disease tells us that beta-cell destruction can be stopped by arresting the inflammatory autoimmune process [3]. Anti-DNA antibodies were found in the sera of diabetes mellitus patients and their presence was also related to the duration of diabetes mellitus and its complications [4] Anti single strand DNA antibodies were also found in the sera of the patients of type 1 diabetes mellitus [5]. Diabetes produces disturbances of lipid profiles, especially an increased susceptibility to lipid peroxidation [6] which is responsible for increase incidence of atherosclerosis [7].a major complication of diabetes mellitus [8]. Diabetic nephropathy is the kidney disease that occurs as a result of diabetes. Cardiovascular and renal complications share common risk factors. The chronic hyperglycemia of diabetes is associated with long-term damage, dysfunction and failure of various organs, especially the eyes, kidneys, nerves, heart and blood vessels. Diabetes affects the kidney in stages. At the onset of diabetes, the kidney grows large and the glomerular filtration rate (GFR) becomes disturbed. Most recent basic and clinical research has pointed toward sclerosis and kidney failure [9].

Subjects, Instruments, Materials and Methods

Subjects: Include eighty (80) samples of female were divided as

A-Patients:

-DM without Cardiovascular.

-nephropathy Complications Group: consists of 20 patients.

-DM with Cardiovascular Complications Group: consists of 20 patients

-DM with Nephropathy

Complications: consists of 20 patients.

\section{B-Controls:}

Twenty healthy subjects were included in this study as control group. None of the controls were diabetic, alcoholic, smoker, or having a history of coronary heart disease, thyroid or other metabolic disease before taking part in this study Type (1).

Their age range was (13-67) years, they were gender and age matched to that of type1 diabetes mellitus. A questionnaire was designed with different questions including duration of diabetes mellitus, family history, 
usage of drugs, drug duration, height, weight, heart disease, and controls group. All diabetic patients with and without cardiovascular and nephropathy complications were treated with insulin injection. Diabetic patients were examined by an endocrinologist in National Diabetes Center (NDC), Patients with thyroid function disease, and hormonal abnormalities were excluded from the study. Patients and controls were classified according to the following:

\section{Table (1)}

Distribution of study Participant according to the Health's status and Age range.

\begin{tabular}{|c|c||c||}
\hline Groups & No. & $\begin{array}{c}\text { Age range } \\
\text { (Years) }\end{array}$ \\
\hline \hline $\begin{array}{c}\text { DM without } \\
\text { complications }\end{array}$ & 20 & $24-50$ \\
\hline $\begin{array}{c}\text { DM with CV } \\
\text { complications }\end{array}$ & 20 & $22-66$ \\
\hline $\begin{array}{c}\text { DM with NP } \\
\text { complications }\end{array}$ & 20 & $13-67$ \\
\hline Controls & 20 & $17-65$ \\
\hline
\end{tabular}

\section{Instruments}

Table (2)

Instruments and Their Companies.

\begin{tabular}{|l|c|}
\hline \multicolumn{1}{|c|}{ Instruments } & Company \\
\hline \hline spectrophotometer & Cencil \\
\hline \hline centrifuge & Hettachi \\
\hline Incubator & memert \\
\hline $\begin{array}{l}\text { ELISA: Microplate } \\
\text { Reader Model }\end{array}$ & Bio-RAD \\
\hline
\end{tabular}

\section{Statistical and analysis}

Using ANOVA Test, Significant using Students-t-test for two independent means at 0.05 level of significance.

Principle: Serum autoimuno antibody was determined to quantitative and qualitative detection of $\operatorname{IgG}, \operatorname{Ig} \mathrm{A}$ and $\operatorname{IgM}$ antibodies against DNA in human serum (AESKULISA Company, Germany ${ }^{10}$.
Materials and Methods

Determination of Serum Level of autoimuno antibody

- Kit Contents

\begin{tabular}{|c|c|c|}
\hline Reagent & Materials & Preparation \\
\hline Item A & \begin{tabular}{|l} 
Sample Buffer \\
Concentrate (tris, \\
Nacl, Tween20, \\
sodiumazide)
\end{tabular} & \begin{tabular}{|l} 
Dilute the \\
concentrated \\
sample buffer 1:5 \\
with distilled \\
water
\end{tabular} \\
\hline Item B & $\begin{array}{l}\text { Wash Buffer } \\
\text { Concentrate (tris, } \\
\text { Nacl, Tween20, } \\
\text { sodiumazide) }\end{array}$ & $\begin{array}{l}\text { Dilute the } \\
\text { concentrated wash } \\
\text { buffer 1:50 with } \\
\text { distilled water }\end{array}$ \\
\hline Item C & $\begin{array}{l}\text { Negative control } \\
\text { Human serum, } \\
\text { sodium azide }\end{array}$ & Ready to use \\
\hline Item D & \begin{tabular}{|l} 
Positive control \\
Human serum, \\
sodium azide \\
\end{tabular} & Ready to use \\
\hline Item E & $\begin{array}{l}\text { Cut-off calibrator } \\
\text { Human serum, } \\
\text { sodium azide }\end{array}$ & Ready to use \\
\hline Item F & \begin{tabular}{|l} 
Calibrators \\
Human serum, \\
sodium azide \\
\end{tabular} & Ready to use. \\
\hline Item G & \begin{tabular}{|l} 
Conjugate \\
Anti-human \\
conjecated with \\
horseradish \\
peroxide \\
\end{tabular} & Ready to use \\
\hline Item H & TMB substrate & Ready to use \\
\hline Item I & $\begin{array}{l}\text { Stop Solution } \\
\text { (hydrochloric } \\
\text { acid) }\end{array}$ & Ready to use \\
\hline Item N & $\begin{array}{l}\text { Microtiterplate } \\
12 \times 8 \text { wellstrips } \\
\text { with break away } \\
\text { microwells } \\
\end{array}$ & \begin{tabular}{|l}
96 wells $(12$ strips \\
x 8 wells)
\end{tabular} \\
\hline
\end{tabular}

\section{Assay Procedure}

The assay was carried out following the instructions in the kit's leaflet, which are summarized in the following steps:

1. Samples were diluted before starting with the test procedure. Dilute sample buffer 1:5 with distilled water according to the following scheme: Dilution: $20 \mu \mathrm{l}$ sample buffer $+80 \mu 1$ distilled water.

2. Dilute wash buffer 1:50 with distilled water according to the following scheme: 
Dilution: $20 \mu \mathrm{l}$ wash buffer $+980 \mu \mathrm{l}$ distilled water.

3. Dilute serum 1:50 with sample Buffer (1x) according to the following scheme: Dilution: $10 \mu$ l sample $+1000 \mu 1$ sample Buffer (1x).

4. The microwell strips were washed twice with approximately $300 \mu \mathrm{l}$ Wash Buffer per well. The Wash Buffer was allowed to sit in the wells for about 20 seconds. Discard liquid from wells inverting the plate. The microwell strips were used immediately after washing.

5. Pipette $(100 \mu \mathrm{l})$ of diluted serum into microwells.

6. Pipette $(100 \mu \mathrm{l})$ calibrators or cut-off calibrators and negative and positive controls into microwells.

7. incubated at $\left(20^{\circ}\right.$ to $\left.32^{\circ} \mathrm{C}\right)$ ) for $30 \mathrm{~min}$ microwell.

8. strips were washed 3 time with $300 \mu \mathrm{l}$ wash buffer dilution.

9. An aliquot $(100 \mu \mathrm{l})$ of diluted conjugate was added to all wells, including the blank wells.

10. incubated at $\left(20^{\circ}\right.$ to $\left.30^{\circ} \mathrm{C}\right)$ for $30 \mathrm{~min}$.

11. The microwell strips were washed 3 times with $300 \mu 1$ wash buffer dilution.

12. An aliquot $(100 \mu \mathrm{l})$ of TMB Substrate Solution was pipette to all wells.

13. The microwell splate were incubated at $\left(20^{\circ}\right.$ to $32^{\circ} \mathrm{C}$ ) for about $30 \mathrm{~min}$.

14. The enzyme reaction was stopped by quickly pipetting $100 \mu \mathrm{l}$ of Stop Solution into each well.

15. The absorbance was read of each microwell on spectrophotometer using $450 \mathrm{~nm}$ as the primary wavelength.

\section{Determination of Serum Glucose}

By using an enzymatic colorimetric method with a commercially available kit, the fasting plasma glucose (FPG) was determined [11] according to Scheme (1).

\section{Determination of Serum Total Cholesterol (S.T.C.)}

Serum cholesterol is measured by cholesterol kit, using an enzymatic method based on the following reactions [12] according to Scheme (2).

\section{Determination of Serum Triacylglycerol (S.TAG)}

Serum triacylglycerol is measured by triacylglycerol kit, using an enzymatic method based on the following reactions [13]: according to Scheme (3).

\section{Determination of Serum High Density Lipoprotein- Cholesterol (S.HDL-C)}

Serum HDL-C is measured by HDL-C kit, using the method of Burstein et al., 1980 [14].

\section{Determination of Serum Low Density Lipoprotein- Cholesterol (S.LDL-C) \\ LDL-cholesterol is very difficult to isolate} and measure. Hence, LDL level is most usually derived by the friedwalds formula as follows [15].

LDL-cholesterol $=$ Total cholesterol $-[$ HDLcholesterol + TG/5]

\section{Determination of Serum S.VLDL- C}

Very low-density lipoprotein- cholesterol was estimated by using formula of friedwald [16] VLDL-Ch $=$ TG/5.

\section{Determination of Serum Urea}

Enzymatic determination of urea concentration (urease-modified Berthelot eactionr [17], urease hydrolysis urea by product ammonium: according to Scheme (4). 


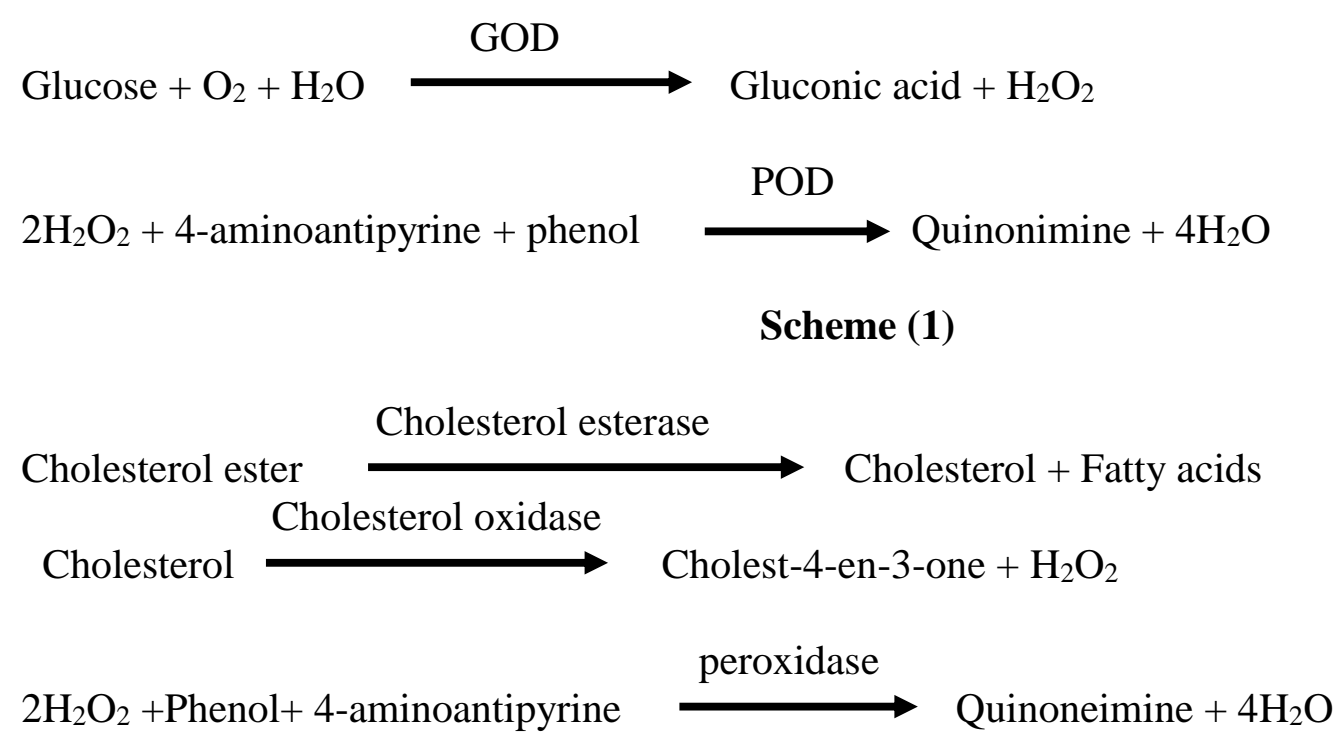

Scheme (2)
Glycerol-3-phosphate $\stackrel{\text { oxidase }}{\longrightarrow}$ Dihydroxyacetone phosphate $+\mathrm{H}_{2} \mathrm{O}_{2}$

Peroxidase

\section{Scheme (3)}

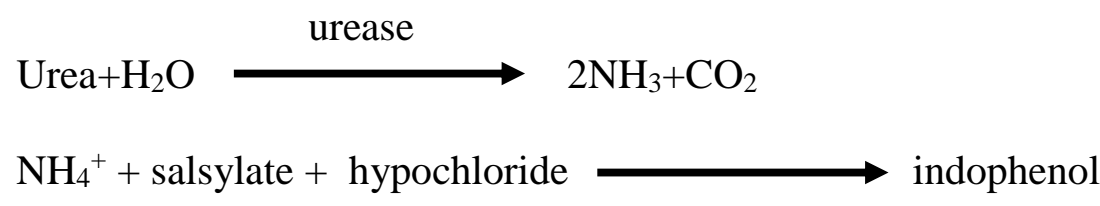

\section{Scheme (4).}

\section{Result}

The means $( \pm \mathrm{SD})$ of age are shown in Table (3). In all patient groups, the means of age were greater than in the control subjects. In addition, there was significant difference $(p=0.01)$ between the means of age in DM patients and control groups. Also the means $( \pm \mathrm{SD})$ of DM duration are shown in Table (3). There was no significant difference between the means of duration in DM with/without complications compared with control groups the means $( \pm$ SD) of BMI are shown in Table (3). In all patient groups. Also the means $( \pm \mathrm{SD})$ of fasting glucose are shown in Table (3). In all patient groups, the means of fasting glucose were greater than in the control subjects. There was not a significant difference $(\mathrm{P}>0.05)$ between the means of DM with/ without complications compared with control groups as shown in Table (3) and Fig.(1). 
Table (3)

Mean of Fasting blood sugar, age, duration of Diabetes Mellitus in DM groups compared to control groups.

\begin{tabular}{|c|c|c|c|c|c|}
\hline & Control & $\begin{array}{c}\text { DM without } \\
\text { complications }\end{array}$ & $\begin{array}{c}\text { DM with } \\
\text { nephropathy }\end{array}$ & $\begin{array}{c}\text { DM with } \\
\text { Vascular disease } \\
\end{array}$ & P.value \\
\hline Valid N & 20 & 20 & 20 & 20 & - \\
\hline Age (year) & $33.65 \pm 6.3$ & $43.45 \pm 16.14$ & $50.65 \pm 13.56$ & $51 \pm 12.06$ & 0.01 \\
\hline Duration of DM & $\begin{array}{l} \\
\end{array}$ & $6.5 \pm 5.13$ & $7.45 \pm 5.32$ & $8.4 \pm 5.69$ & 0.6 \\
\hline $\begin{array}{c}\text { Mean } \pm S D \\
F B G(m g / d l)\end{array}$ & $88.63 \pm 8.47$ & $229.05 \pm 91.63$ & $231.1 \pm 97.84$ & $241.1 \pm 105.51$ & 0.9 \\
\hline
\end{tabular}

Data demonstrated by Table (4) shows Total serum cholesterol levels were significantly $(\mathrm{p}=0.04)$ higher in DM patients when compared with controls (154 \pm $30.3 \mathrm{mg} / \mathrm{dl})$ Vs. $(157.05 \pm 28.4 \mathrm{mg} / \mathrm{dl})$ for $\mathrm{DM}$ patients and controls respectively.

Total serum cholesterol In DM with nephropathy patients and DM with CV patients was $(182.9 \pm 45.6 \mathrm{mg} / \mathrm{dl})$ and $(238.5 \pm 44.9 \mathrm{mg} / \mathrm{dl})$ there was no significant difference $(\mathrm{P}>0.05)$ could be detected compared to mean control $(154 \pm 30.3)$ as shown in Table (4) and Fig.(2).

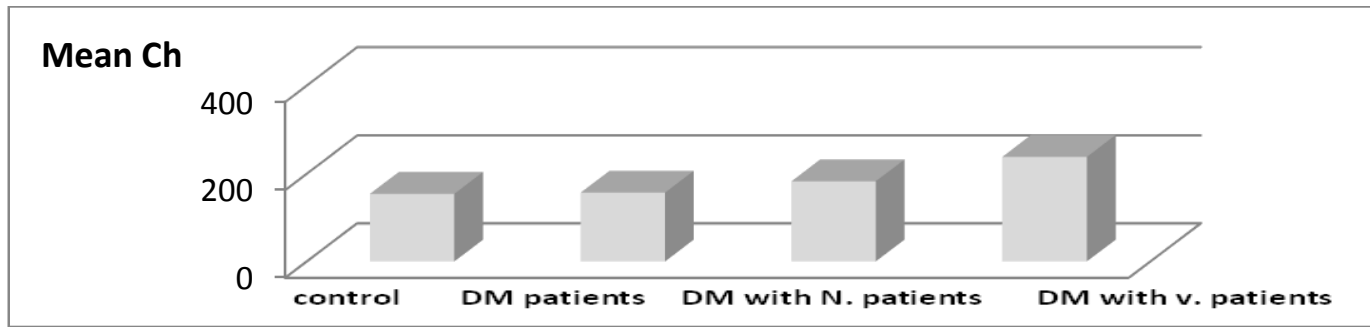

Fig.(1) The mean of serum Glucose level (mg/dl) in Diabetes Mellitus groups and control groups.

Table (4).

\begin{tabular}{|c|c|c|c|c|c|}
\hline Mean $\pm S D$ & Controls & $\begin{array}{l}\text { DM without } \\
\text { complications }\end{array}$ & $\begin{array}{c}\text { DM with } \\
\text { nephropathy }\end{array}$ & $\begin{array}{l}\text { DM with } C V \\
\text { complications }\end{array}$ & $\begin{array}{c}P \\
\text { value }\end{array}$ \\
\hline S.cholesrol (mg/dl) & $154 \pm 30.3$ & $157.05 \pm 28.4$ & $182.9 \pm 45.6$ & $238.5 \pm 44.9$ & 0.04 \\
\hline Triglycerid $(\mathrm{mg} / \mathrm{dl})$ & $96.88 \pm 21.3$ & $106 \pm 41.5$ & $142.6 \pm 58.2$ & $198 \pm 102.8$ & 0.004 \\
\hline$H D L(m g / d l)$ & $51.62 \pm 2.95$ & $50.5 \pm 5.6$ & $45.68 \pm 6.07$ & $40.7 \pm 5.68$ & 0.0008 \\
\hline$\overline{L D L}(\mathrm{mg} / \mathrm{dl})$ & $77.29 \pm 24.72$ & $82.6 \pm 28.3$ & $100.7 \pm 50.7$ & $153.7 \pm 44.3$ & 0.08 \\
\hline$V L D L(m g / d l)$ & $20 \pm 5.09$ & $24.8 \pm 15.2$ & $28.15 \pm 11.8$ & $42.6 \pm 21.53$ & 0.01 \\
\hline $\begin{array}{c}\text { Atherogenic Index } \\
(\text { LDL/HDL)ratio }\end{array}$ & $1.53 \pm 0.54$ & $1.58 \pm 0.55$ & $2.15 \pm 1.37$ & $3.82 \pm 1.17$ & 0.08 \\
\hline $\begin{array}{l}\text { LDL Size Index } \\
(T G / H D L) \text { ratio }\end{array}$ & $1.91 \pm 0.81$ & $2.1 \pm 1.06$ & $3.29 \pm 1.71$ & $5.21 \pm 3.03$ & 0.003 \\
\hline
\end{tabular}

Lipid profile in Diabetus Mellitus groups compared to control groups. 


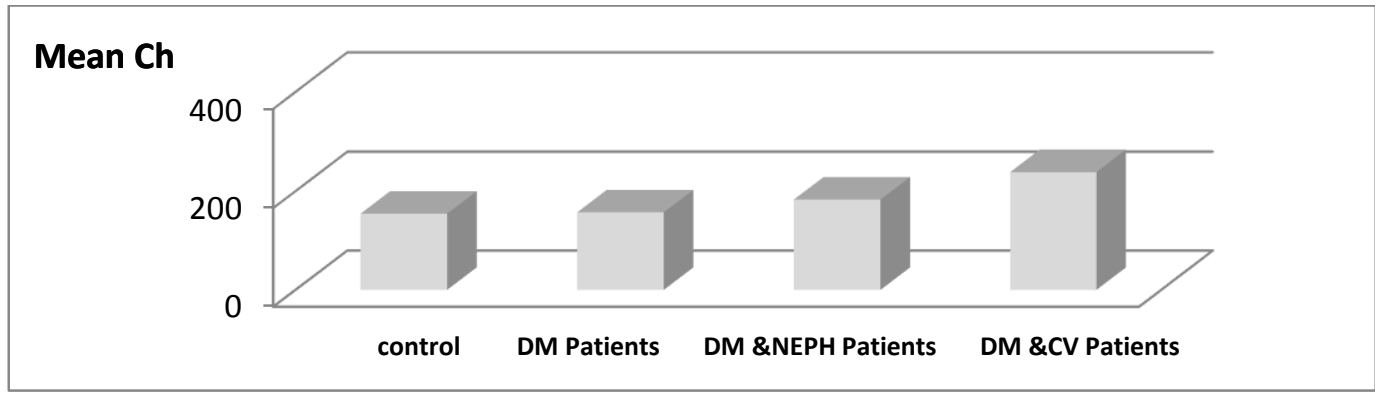

Fig.(2) The mean of serum S.cholesterol level (mg/dl) in Diabetus Mellitus groups and control groups.

Triglyceride was found to be significantly higher $(\mathrm{p}=0.004)$ in $\mathrm{DM}$ patients with means of $(106 \pm 41.5 \mathrm{mg} / \mathrm{dl})$ compared to control with a mean of $(96.88 \pm 21.3 \mathrm{mg} / \mathrm{dl})$. serum Triglyceride In DM with nephropathy patients and DM with CV patients was
$(142.6 \pm 58.2 \mathrm{mg} / \mathrm{dl})$ and $(198 \pm 102.8 \mathrm{mg} / \mathrm{dl})$ there was no significant difference $(\mathrm{P}>0.05)$ could be detected compared to control as shown in Table (4) and Fig.(3).

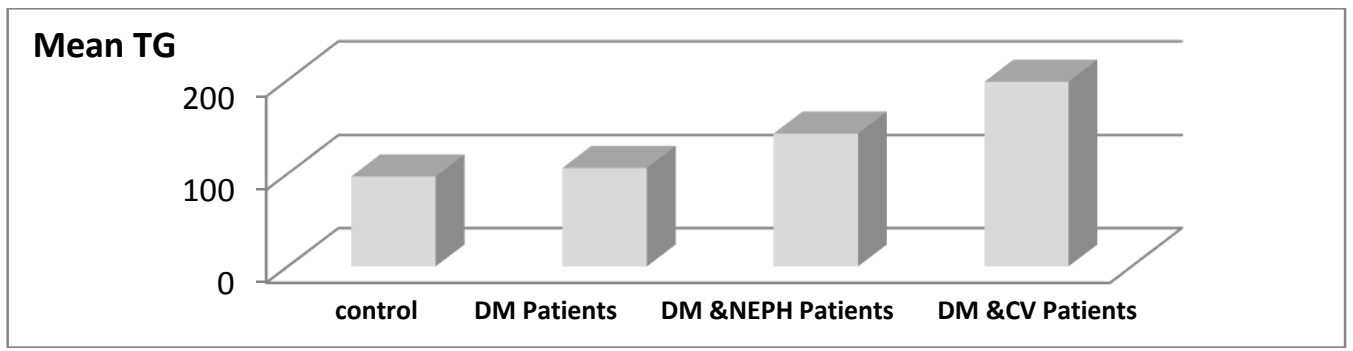

Fig. (3) The mean of serum Tri Glyceride level (mg/dl) in Diabetus Mellitus groups and control groups.

The mean serum level of HDL-cholesterol slightly decrease in the DM patients $(50.5 \pm$ $5.6 \mathrm{mg} / \mathrm{dl}$ ) when compared to that found in the control group $(51.62 \pm 2.95 \mathrm{mg} / \mathrm{dl})$ but the difference was not significant $(\mathrm{P}>0.05)$ while in DM with nephropathy patients and DM with
$\mathrm{CV}$ patients $((45.68 \pm 6.07 \mathrm{mg} / \mathrm{dl})$ and $(40.7 \pm 5.68 \mathrm{mg} / \mathrm{dl})$ when compared to control as shown in table (4) and Fig. (4).

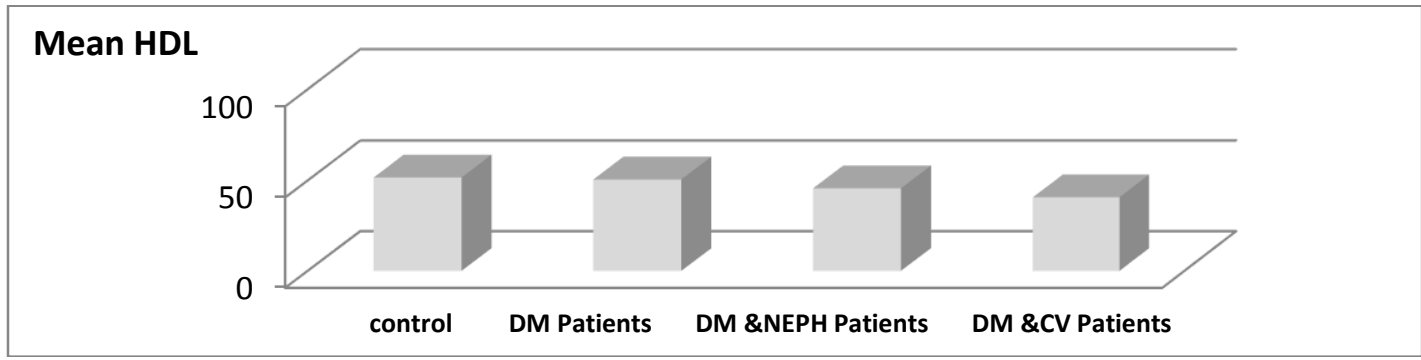

Fig. (4) The mean of serum High density lipoprotein level (mg/dl) in Diabetus Mellitus groups and control groups.

LDL-cholesterol levels were not significantly $(\mathrm{p}=0.08)$ higher in DM patients when compared with controls $(82.6 \pm 28.3 \mathrm{mg} / \mathrm{dl})$ vs. $(77.29 \pm 24.72 \mathrm{mg} / \mathrm{dl})$ for 
DM patients and controls respectively as shown in Fig.(4), while in DM with nephropathy patients and DM with $\mathrm{CV}$ patients $\quad(100.7 \pm 50.7 \mathrm{mg} / \mathrm{dl})$ and $\quad(153.7$ $\pm 44.3 \mathrm{mg} / \mathrm{dl})$ no significant difference $(\mathrm{P}>0.05)$ when compared to control as shown in Table (4) and Fig. (5).

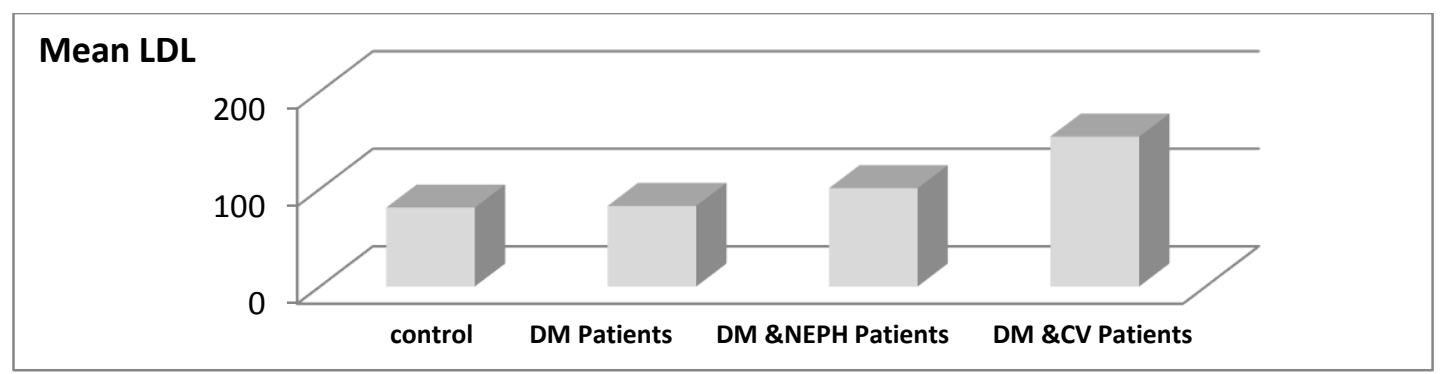

Fig. (5) The mean of serum Low density lipoprotein level (mg/dl) in Diabetus Mellitus groups and control groups.

There was not significant $(\mathrm{p}=0.01)$ difference in mean VLDL-cholesterol $(24.8 \pm 15.2 \mathrm{mg} / \mathrm{dl})$ in $\mathrm{DM}$ patients than in the control group $(20 \pm 5.09 \mathrm{mg} / \mathrm{dl})$. Table (4) also show no a significant difference $(\mathrm{P}>0.05)$ between in DM with nephropathy patients and
DM with CV patients $(28.15 \pm 11.8 \mathrm{mg} / \mathrm{dl})$ and $(42.6 \pm 21.53 \mathrm{mg} / \mathrm{dl})$ when compared with control show in Fig. (6).

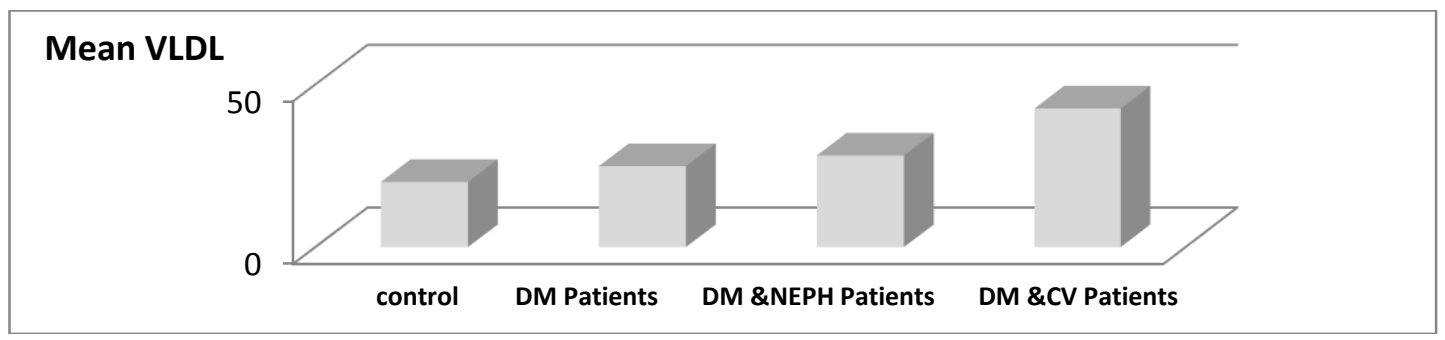

Fig. (6) The mean of serum Very low density lipoprotein level (mg/dl) in Diabetus Mellitus groups and control groups.

This study reveals increased levels of TC, TAG, LDL-C, and decreased levels of HDL-C compared with control showed that female diabetic patients had significantly higher levels of cholesterol, Hyperlipidemia in females may be attributed to the effects of sex hormones on body fat distribution, leading to differences in altered [18]. Also High HDL levels protect against $\mathrm{CV}$ development, as patients with high HDL tend to have lower prevalence of CV risk factors. On the other hand, patients with low levels of HDL are more likely to develop CV disease [19]. The serum Serum Atherogenic mean LDL/HDL values were $(1.58 \pm 0.55)$ for $\mathrm{DM}$ and control patients $(1.53 \pm 0.54)$ as shown in Fig.(7). Serum Atherogenic value were found to be not significantly elevated in DM with nephropathy patients level $(2.15 \pm 1.37)$ patients group and also the mean of DM with vascular disease $(3.82 \pm 1.17)$ compared to control, Table (4) Fig.(7), Serum Atherogenic LDL-C/HDL-C ratio value were found to be elevated in diabetes mellitus patients as compared with control, Several large clinical studies have found the LDL-C/HDL-C ratio to be an excellent predictor of CV risk [20]. 


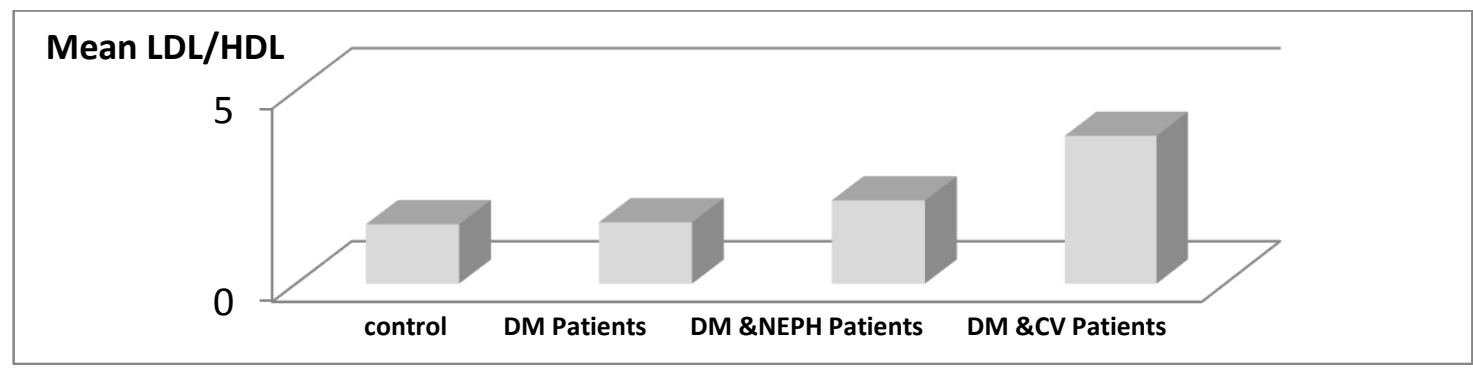

Fig. (7) The mean of serum Low Density Lipoprotein-C/High Density Lipoprotein-C) (LDL/HDL) Ratio level (mg/dl) in Diabetus Mellitus groups and control groups.

The means of Atheogenic Index Serum TG/HDL-C are shown in Table (4), Fig. (8). In mean DM patient $(2.1 \pm 1.06)$, the means of Serum LDLs were significantly $(\mathrm{p}=0.003)$ than in mean control, $(1.91 \pm 0.81)$ subjects, There was not significant difference between the means of DM with nephropathy patients $(3.29 \pm 1.71)$ with the mean of control $(1.91 \pm 0.81)$, also the mean of DM with vascular disease $(5.21 \pm 3.03)$ not significantly $(\mathrm{p}=0.9)$ when compared with to mean controls (1.91 \pm 0.81$)$. Also serum of Atherogenic Index TG/HDL show increase in mean of DM patient compared with control [21].The presence of hypertriglyceridemia, low HDL-C concentrations, and high TG/HDL-C ratio associated with insulin resistance because insulin affects TAG and HDL-C metabolism [22].

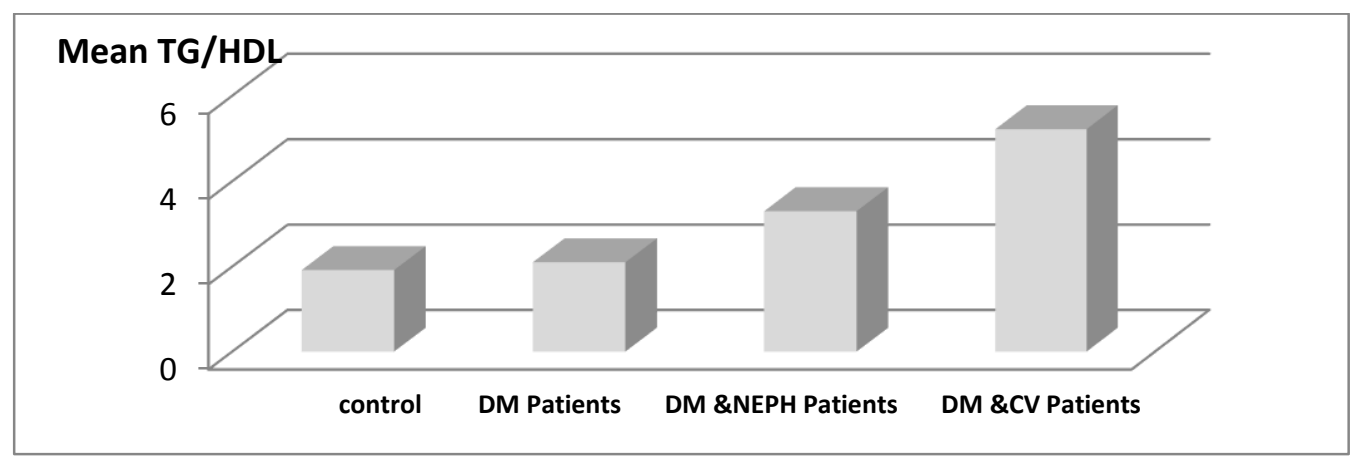

Fig. (8) The mean of serum (Triglyceride/High density lipoprotein-C))TG/HDL Ratio level (mg/dl) in Diabetus Mellitus groups and control groups.

BMI was found to be significantly [p=0.03] in DM patients with a mean of $\left(29.28 \pm 7.22 \mathrm{Kg} / \mathrm{m}^{2}\right)$ compared to controls with a mean of $\left(24.19 \pm 2.57 \mathrm{Kg} / \mathrm{m}^{2}\right)$, and a significant difference was found $(p=0.01)$ between DM with nephropathy patients $\left(28.25 \pm 4.14 \mathrm{Kg} / \mathrm{m}^{2}\right)$ and control $\left(24.19 \pm 2.57 \mathrm{Kg} / \mathrm{m}^{2}\right)$, also significant difference $(\mathrm{p}=0.0005)$ was found between $\mathrm{DM}$ with vascular patients $\left(31.53 \pm 6.22 \mathrm{Kg} / \mathrm{m}^{2}\right)$ and mean control $\left(24.19 \pm 2.57 \mathrm{Kg} / \mathrm{m}^{2}\right)$ as shown in Table (5), Fig.(9) BMI was found increased in DM patients with a mean of compared to controls Although BMI is a measure of overall adiposity, it is often considered an indicator of body fatness; it is a surrogate measure of body fat because it measures excess weight rather than excess fat [23]. 
Table (5)

Mean of Body Mass Index (BMI) in Diabetus Mellitus groups compared to control groups.

\begin{tabular}{|c|c|c|c|c|}
\hline Mean $\pm S D$ & Controls & $\begin{array}{c}\text { DM without } \\
\text { complications }\end{array}$ & $\begin{array}{c}\text { DM with } \\
\text { nephropathy }\end{array}$ & $\begin{array}{c}\text { DM with CV } \\
\text { complications }\end{array}$ \\
\hline$B M I\left(K g / m^{2}\right)$ & $24.19 \pm 2.57$ & $29.28 \pm 7.22$ & $28.25 \pm 4.14$ & $31.53 \pm 6.22$ \\
\hline $\begin{array}{c}\text { P.Value compared with } \\
\text { control }\end{array}$ & - & 0.03 & 0.01 & 0.0005 \\
\hline
\end{tabular}

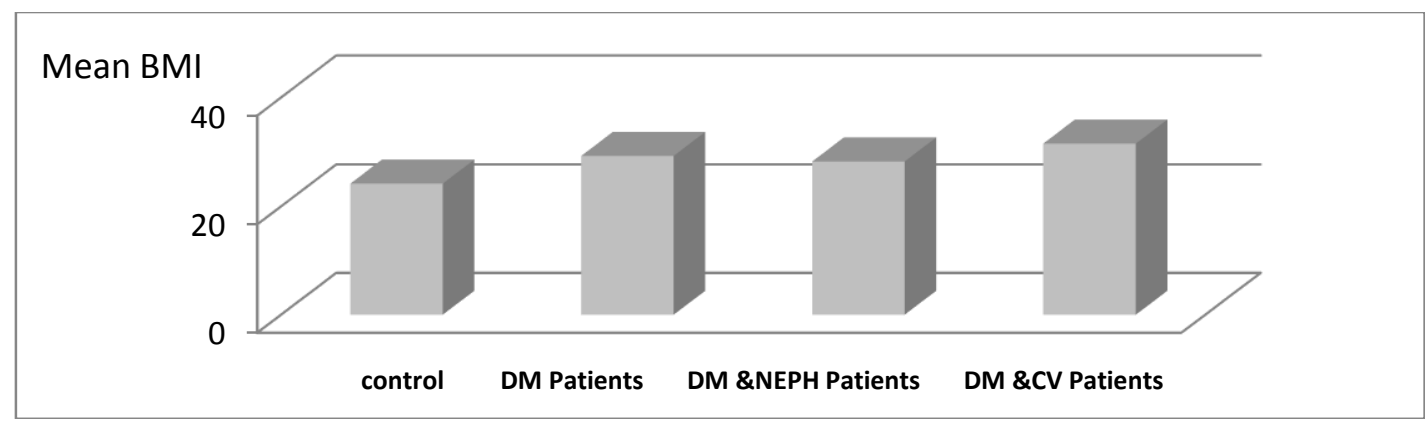

Fig. (9) The mean of Body Mass Index (BMI) level (mg/dl) in Diabetus Mellitus groups and control groups.

The means $( \pm$ SD) of Percent Body Fat (PBF) are shown in Table (6). In all patient groups, the means of PBF were greater than in the control subjects, There was significant difference $(\mathrm{p}=0.0008)$ between the means of PBF in DM patients $(40.14 \pm 10.58)$ with the mean of control $(30.13 \pm 5.67)$ The mean of DM with nephropathy patients level $(40.16 \pm 6.08)$ was not significantly $(\mathrm{p}=0.9)$ as compared to mean controls $(30.13 \pm 5.67)$, also the mean of DM with vascular disease (44.50 \pm 7.86$)$ not significantly $(\mathrm{p}=0.9)$ when compared with to mean controls $30.13 \pm 5.67$ ) shown in Table (6) Fig. (10).

In all patient groups, the means of PBF were greater than in the control subjects Clinical evidence suggests that the association of diabetes with central obesity is stronger than the association with general fat. Central obesity has been associated with decreased glucose Tolerance, reduced metabolic clearance of insulin, and decreased insulinstimulated glucose disposal. With the rapidly increasing diabetic population in our country [24]. 
Table (6)

Mean Percent Body Fat (PBF) in Diabetus Mellitus groups compared to control groups.

\begin{tabular}{|c|c||c||c||c||}
\hline Mean \pm SD & Controls & $\begin{array}{c}\text { DM without } \\
\text { complications }\end{array}$ & $\begin{array}{c}\text { DM with } \\
\text { nephropathy }\end{array}$ & $\begin{array}{c}\text { DM with CV } \\
\text { complicatios }\end{array}$ \\
\hline \hline PBF & $30.13 \pm 5.67$ & $40.14 \pm 10.58$ & $40.16 \pm 6.08$ & $44.50 \pm 7.86$ \\
\hline $\begin{array}{c}\text { P.Value } \\
\text { compared with } \\
\text { control }\end{array}$ & - & 0.0008 & 0.9 & 0.9 \\
\hline
\end{tabular}

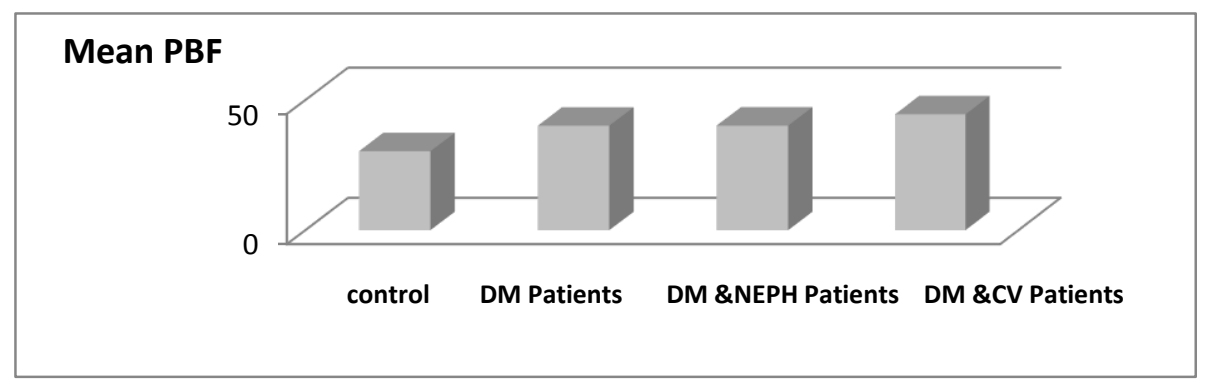

Fig. (10) The mean of Percent Body Mass (PBF) level (mg/dl) in Diabetus Mellitus groups and control groups.

Autoantibody was found to be significantly $[\mathrm{p}=0.02]$ in $\mathrm{DM}$ patients with a mean of $(0.32 \pm$ 0.12 ) compared to controls with a mean of $(0.24 \pm 0.04)$, and a significant difference was found $\quad(p=0.0007)$ between DM with nephropathy patients $(0.34 \pm 0.1)$ and control $(0.25 \pm 0.05)$, also not significant difference $(\mathrm{p}=0.1)$ was found between DM with vascular patients $(0.27 \pm 0.07)$ and mean control $(0.24 \pm 0.04)$ as shown in Table (7), Fig. (11).
In addition of that the disruption of insulin synthesis is caused by immunological destruction of the islet cells by autoantibodies in IDDM patient. Immunological Autoantibody was found to increased in DM patients compared to control [25].

Table (7)

Mean of Autoantibody in Diabetus Mellitus groups compared to control groups.

\begin{tabular}{|c|c|c|c|c|}
\hline ELISA $(U / m l)$ & Control & $\begin{array}{l}\text { DM without } \\
\text { complications }\end{array}$ & $\begin{array}{c}\text { DM with } \\
\text { Nephropathy } \\
\text { complication } \\
\end{array}$ & $\begin{array}{l}\text { DM with } C V \\
\text { complication }\end{array}$ \\
\hline Valid N & 20 & 20 & 20 & 20 \\
\hline$M e a n \pm S D$ & $0.24 \pm 0.04$ & $0.32 \pm 0.12$ & $0.34 \pm 0.1$ & $0.27 \pm \quad 0.07$ \\
\hline $\begin{array}{c}P \text { value compared } \\
\text { with control }\end{array}$ & - & 0.02 & 0.0007 & 0.1 \\
\hline
\end{tabular}




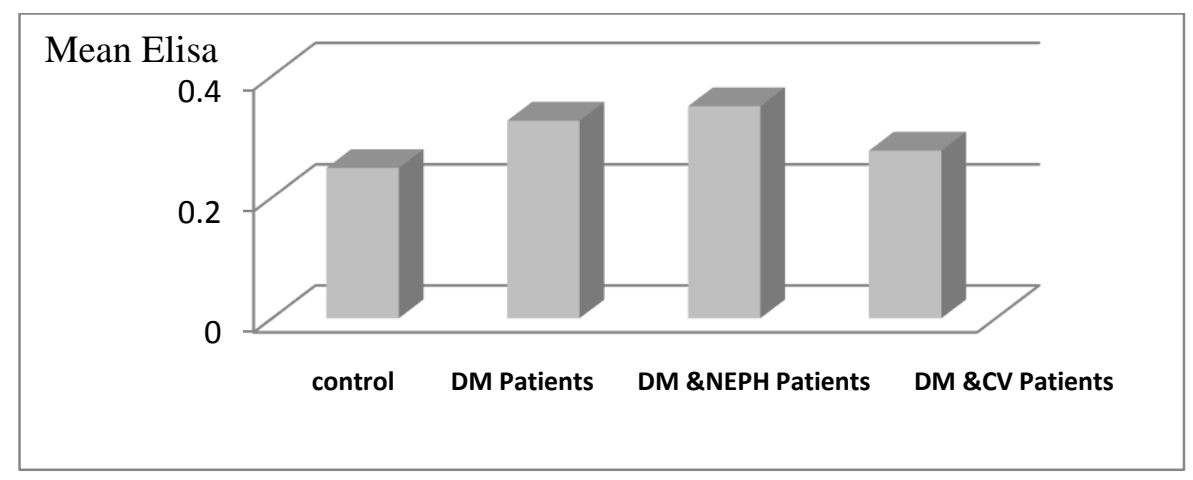

Fig. (11) The mean of Autoantibody level (mg/dl) in Diabetus Mellitus groups and control groups.

Urea was found to be significantly $[\mathrm{p}=0.02]$ in DM patients with a mean of (26.25 \pm 3.84$)$ compared to controls with a mean of (23.25 \pm 4.03$)$, and a significant difference was found $(\mathrm{p}=0.01)$ between $\mathrm{DM}$ with nephropathy patients $(41.9 \pm 6.07)$ and control (23.25 \pm 4.03$)$, also significant difference $(\mathrm{p}=0.005)$ was found between DM with vascular patients $(26.6 \pm 2.92)$ and mean control (23.25 \pm 4.03$)$ as shown in Table (8), Fig. (12), in the present investigation, diabetes associated nephropathy (DM+NP) Clinical abnormalities are often detected 5-10 years after onset or diagnosis of DM. The patient to be Nephropathy DM [26].

Table (8)

Mean of Urea in Diabetus Mellitus groups compared to control groups.

\begin{tabular}{|c||c||c||c|c||}
\hline Urea $(\mathrm{mg} / \mathrm{ml})$ & Control & $\begin{array}{c}\text { DM without } \\
\text { complications }\end{array}$ & $\begin{array}{c}\text { DM with } \\
\text { nephropathy } \\
\text { disease }\end{array}$ & $\begin{array}{c}\text { DM with CV } \\
\text { disease }\end{array}$ \\
\hline \hline Valid $N$ & 20 & 20 & 20 & 20 \\
\hline \hline $\begin{array}{c}\text { Mean } \pm S D \\
\text { control }\end{array}$ & $23.25 \pm 4.03$ & $26.25 \pm 3.84$ & $41.9 \pm 6.07$ & $26.6 \pm 2.92$ \\
\hline $\begin{array}{c}\text { P value compared with } \\
\text { contron }\end{array}$ & 0.02 & 0.01 & 0.005 \\
\hline
\end{tabular}

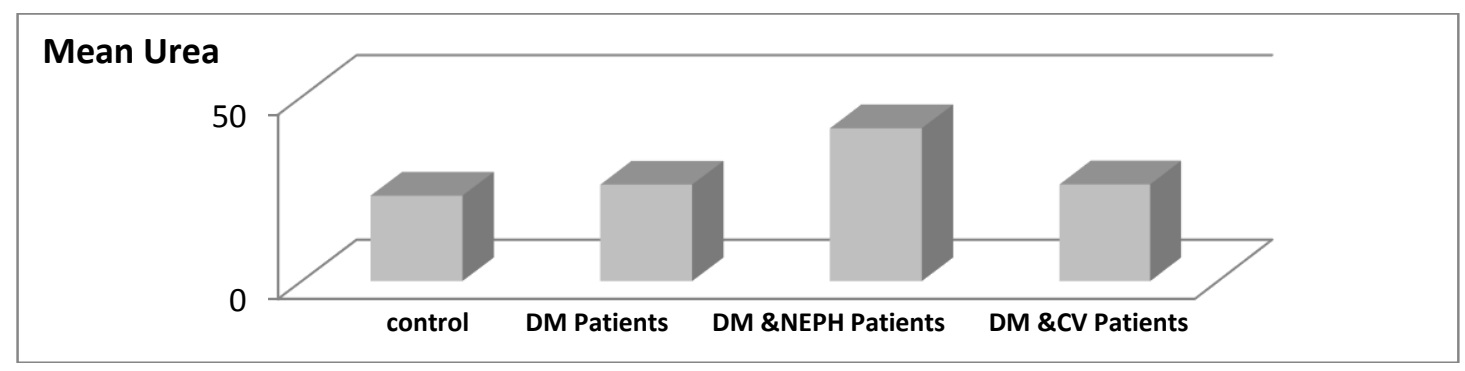

Fig.(12) The mean of serum Urea level (mg/dl) in Diabetus Mellitus groups and control groups. 


\section{References}

[1] ADA (American Diabetes Association), "Diagnosis and classification of diabetes mellitus", J.Diabetes, Care, 28(1), S37S43, 2005.

[2] Bach JF, "Insulin-dependent diabetes mellitus as an autoimmune disease", J.Endocr Rev , 15:516-542,1994.

[3] Bougneres PF, Carel JC, Castano L et al. "Factors associated with early remission of type I diabetes in children treated with cyclosporine", J. Med 318:663-670, 1988.

[4] Yokokawa N, Aizawa T, Ishihara M, Koizumi Y, et al Presence of anti-DNA antibodies in diabetes mellitus: its relation to the duration of diabetes and diabetic complications. J.Metabolism, 38:891-894, 1989.

[5] Giardina E, Triolo G, Accardo-Palumbo A, Carbone MC, Gancitano V, Verga S, et al., "Anti-single-stranded DNA antibody in the sera of patients with type 2 diabetesmellitus. Relation to vascular complications", J.Acta Diabetol; 34(1): 3941, 1997.

[6] LYONS, T.J., Oxidized low density lipoproteins: a role in the pathogenesis of atherosclerosis in diabetes, J.Diabet Med., 8, 411-419, 1991.

[7] GIUGLIANO, D, A. CERIELlO, G. PAOLISSO, "Diabetes mellitus, hypertension and cardiovascular diseases: which role for oxidative stress", J. Metabolism, 44, 363-368, 1995.

[8] STEINER, G., "Atherosclerosis, the major complication of diabetes", J.Med. Biol., 189, 277-297, 1985.

[9] Sarika Arora, MD, "Renal function in diabetic nephropathy", World J Diabetes May 15; 1(2): 48-56, 2010.

[10] Witte $\mathrm{T}$, Hartung $\mathrm{K}$, Matthias et al, "Association of IGA anti-dsDNA antibodies withvasculities and disease activity in systemic lupus erythematosus", J.Rheumatol Int, 18:63-69, 1998.

[11] Kaplan L.A. Glucose. Kaplan et al, J.Clin chem.:1032-1036, 1984.

[12] Naito H.K cholesterol. Kalan, A, J.Clin Chem.:1194-11206 and 437, 1984.

[13] Buccolo G. "quanitative determination of serum triglyceride by use of enzymes" J.Clin chem., 19(5):476-48, 1973.
[14] Burstein M., Scholnick H.R. and Scand M.R., "Rapid method for the isolation of lipoproteins from human serum by precipitation with polyanions". Journal Clinical Lab. Invest., 11(6):583-595,1980.

[15] WHO., Physical status: "the use and interpretation of anthropometry", J.World Health Organization, No. 854:1-452, 1995.

[16] Friedewald W., Levy R., Fredrickson D, "Estimation of the concentration of lowdensity lipoprotein cholesterol in plasma without use of the ultracentrifuge", Clin. Chem.; 18: 449-502, 1972.

[17] WILLS. M. R.SAVORY., Aluminum toxicity in relation to kidney disordersJ. biochemistry of renal failure-,11,4,292-299, 1981.

[18] Smellie WS, Hypertriglyceridaemia in diabetes, J.BMJ, 333:1257-1260, 2006.

[19] Haseeb Ahmad Khan, "Clinical significance of $\mathrm{HbAlc}$ as a marker of circulating lipids in male and female type 2 diabetic patients", J.Acta Diabetol, 44 (4): 193-200, 2007.

[20] Fernandez M.L. and Webb D., "The LDL to HDL cholesterol ratio as a valuable tool to evaluate coronary heart disease risk", Journal of the American College., 27(1):15, 2008.

[21] Rosamond W., Flegal K., Furie K. et al., "Heart disease and stroke statistics-update". J.Circulation., 117(4): 25-146, 2008.

[22] Miller M., Cannon C.P., Murphy S.A., et al, "Investigators, Impact of triglyceride levels beyond low-density lipoprotein cholesterol after acute coronary syndrome in the Prove it-Timi 22 trial". J Am Coll Cardiol., 51(7):724-730, 2008.

[23] Tirosh A., Shai I., Afek A., Dubnov-Raz G., Ayalon N., Gordon B., Derazne E., Tzur D., Shamis A., Vinker Sh., and Rudich A., Adolescent BMI trajectory and risk of diabetes versus coronary disease, J. Med., 364(14):1315-1325, 2011.

[24] Ashwin Kamath, G.Shivaprakash, Prabha Adhikari, "The association between lipid profile and Body mass index and Waist circumference in Type 2 Diabetes mellitus patients attending a diabetes clinic", Int $J$ Biol Med ,2(3): 636-638, 2011. 
[25] Rossini, A. A., J.P. Mordes, and E.S. Handler. A "Tumbler hypotheses: The autoimmunity of insulin- dependent diabetes mellitus". J.Diabet. Spect., 2:195201, 1989.

[26] Jianhui Zhou, Xiangmei Chen, Yuansheng Xie, Jianjun Li, Nobuaki Yamanaka an Xinyuan Tong, Nephrol Dial, "A differential diagnostic model of diabetic nephropathy and non-diabetic renal diseases", Nephrol Dial Transplant, 23: 1940-1945, 2008.

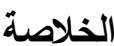

داء السكري من النوع الأول هو مرض سببه تحطم

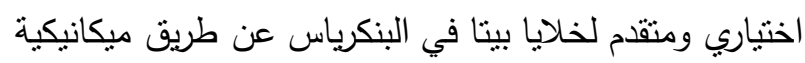

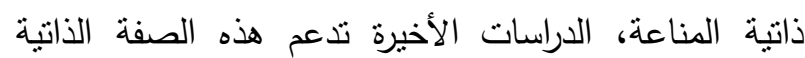

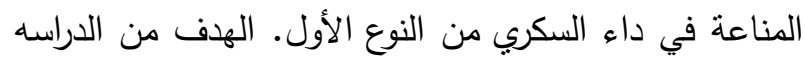
هو الكثف عن الاجسام المضاده من النوع الاول لمرضى لهى السكري مع المضاعفات الكلوية والوعائيه حيث اجريت الدراسه على •N عينه من المصل والدم من النساء وقد تم

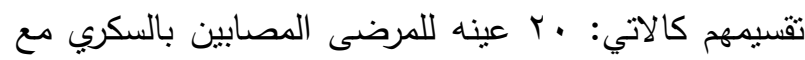

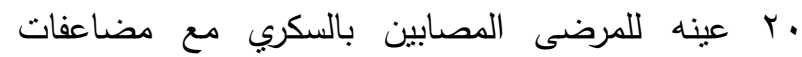
الامراض الوعائيه و . r عينه الدم للمرضى المصابين بالسكري مع المضاعفات الكلويه و . r عينه للاشخاص الاصحاء سريريا وقد تمت الدراسة في المركز الوطني لابحاث السكري ومركز بحوث التقنيات الاحيائيه/ جامعة

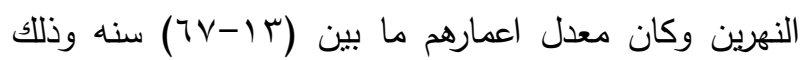
لقياس مستوى اليوريا والدهون والاجسام المضاده. اظهرت مات لترن النتائج وجود ارتفاع في مستوى الدهون واليوريا وكمية الاجسام المضاده لمرضى السكري من النوع الاول مقارنه بمجموعة الاصحاء (مجموعة التحكم). 